\title{
RESEARCH AND CONSERVATION IN MARINA EL-ALAMEIN IN 2014 AND 2015 (POLISH-EGYPTIAN CONSERVATION MISSION) Part one: The Southern Bath and central town square
}

\author{
Rafał Czerner, 'Grażyna Bąkowska-Czerner, Wiesław Grzegorek ${ }^{3}$ \\ and Grzegorz Majcherek ${ }^{4}$ \\ ${ }^{1}$ Wrocław University of Science and Technology, ${ }^{2}$ Jagiellonian University, ${ }^{3}$ independent, PCMA \\ associate, ${ }^{4}$ Polish Centre of Mediterranean Archaeology, University of Warsaw
}

\begin{abstract}
Activities undertaken by the Polish-Egyptian Conservation Mission to Marina el-Alamein in 2014 and 2015 included research and conservation in the public district of the ancient town as well as in private houses. The emphasis was foremost on research, conservation and exhibition of monuments in the area north of the central town square, especially the remains of public baths dating from the Hellenistic period. Research and conservation continued also in the area south of the central square, concentrating on the remains of Roman baths in use from the 2 nd to the 4th century $\mathrm{AD}$. Current maintenance and conservation were carried out in private houses and in the area south of the central square.
\end{abstract}

Keywords: Marina el-Alamein, Southern Bath, town center, houses, architecture, research, preservation, conservation, current maintenance

In 2014 and 2015, mission activities included research and conservation work in the public part of the ancient town of today's Marina el-Alamein [Fig. 1], as well as conservation, to a limited extent, of wall painting relics in storage. In both seasons the mission focused above all on conservation, display of preserved monuments and research in the area of the central town square, in two complexes of public baths: one dating to the Hellenistic period on the north side of the square, and the other Roman on the south side [Fig. 2].
Work in the southern complex had been in progress for several years and the fieldwork in 2014 and 2015 was its continuation. Further elements and rooms of the baths were studied and secured. Research and conservation of the Hellenistic baths was undertaken in 2014 for the first time since they were discovered in 1987 and it was continued in 2015. In various areas of the town, mainly south of the central square, but also on the site of house remains maintenance conservation and preservation were carried out as well. 
Access to wall paintings protected and restored earlier and stored until 2011 without regular inspection, resulted in the need for intervention work on these finds.

The 2015 season celebrated 20 years of fieldwork with an exhibition at the
Alexandria National Museum. The team also took up the challenge of the forthcoming opening of the archaeological site to the public, announced by the Ministry of Antiquities.

\section{MAIN AREAS OF FIELDWORK}

Two complexes of baths were identified already during the first rescue archaeological research undertaken after the discovery of the site in 1985-1987 [Fig. 2]. The northern baths, of the tholos type, discovered by Egyptian and Polish archaeologists, are earlier and of Hellenistic origin (Daszewski 1991: 16; 1995: 15, Fig. 3; 2011: 429; Fournet et al. 2013: 326). The 2014 season was devoted mainly to conservation and preservation activities, carried out under archaeological supervision, and to research. A study of the functional layout of the complex was also undertaken. The 2014 conservation work included, above all, preservation, mainly of the deteriorating walls of the two main chambers. In room 1 (tholos), relics of nine hip-bathtubs, one bigger bathtub, and remains of a red brick dome base were exposed, while the other

Team

Dates of work: 4-29 May 2014; 4-30 May 2015

Director: Prof. Rafał Czerner, architect (Wrocław University of Science and Technology;2014, 2015) SCA representatives: Dr. Khaled Abul-Hamd (Marina Site Director; 2014), Nama Sanad Yakoub (Deputy Director, 2014; Marina Site Director, 2015), Eman Mohamed Abd El Khalek Gomaa (SCA inspector; 2014), Medhat Saleh Kamal Yousif (SCA inspector; 2015)

Archaeologist: Dr. Grażyna Bąkowska-Czerner (Jagiellonian University; 2014, 2015)

Pottery expert: Dr. Grzegorz Majcherek, archaeologist (PCMA UW; 2014, 2015)

Glass expert: Renata Kucharczyk, archaeologist (PCMA UW; 2014, 2015)

Architects: Wiesław Grzegorek (freelance, PCMA associate; 2014, 2015), Marta Grzegorek (MA student, Wrocław University of Science and Technology; 2014), Karolina Majdzik (PhD candidate, Wrocław University of Science and Technology; 2015)

Stone and sculpture conservators: Piotr Zambrzycki (Inter-Academy Institute of Conservation and Restoration of Works of Art; 2014, 2015), Wojciech Osiak (freelance; 2014, 2015)

Painting conservator: Marlena Koczorowska (freelance, 2014; Academy of Fine Arts, Warsaw, 2015)

\section{Acknowledgments}

The assistance of General Directors of the Marina el-Alamein site Dr. Khaled Abul-Hamd and Mrs. Nama Sanad Yakoub, and inspectors Mrs. Eman Mohamed Abd El Khalek Gomaa and Mr. Medhat Saleh Kamal Yousif during both seasons is gratefully appreciated. The two seasons were brief, but effective and this we owe largely to our Egyptian hosts who were instrumental in facilitating all the extraordinary feats of these seasons. Prof. Andrzej Koss, Director of the Inter-Academy Institute of Conservation and Restoration of Works of Art, paid a brief visit to the site. 
room (2a) contained an immersion bathtub, and stairs. Some walls of other rooms were also preserved.

Work in the Hellenistic baths in 2015 focused mainly on clearing the rooms in the southern area of the complex. At first, stone blocks gathered there and material deposited since the end of the initial investigations in 1987, were removed to permit further archaeological exploration. The functional layout of the baths and their transformation could then be studied (for a detailed report, see Czerner et al. 2016: $167 \mathrm{ff}$, in this volume). From a conservation point of view, exposing the layout was very important. It was followed by partial restoration and protection of the remains.

The Roman baths and the civic basilica adjacent to them were connected by a passage. Both structures were excavated by the Polish Archaeological Mission run by Professor Wiktor A. Daszewski in
1987 (Daszewski 1995: 19-20) and again in 2005 (Daszewski et al. 2007: 79-82). In 2006 and 2007, the baths were excavated further by Egyptian archaeologists contracted by MASP, an American ARCE/EAP project. The Polish-Egyptian Conservation Mission has continued conservation and research work in the complex since 2007 (Medeksza et al. 2011: 116-118; 2012: 84-99). In the 2014 season, further rooms in the baths were cleared in the southern part: room 14 housing a latrine, separate from another one situated in room 12 , room 15 , as well as relics of a furnace (7a), and room 10 with remains of a hypocaustum, neighboring on the caldarium (7) [Fig. 3]. All three rooms were subjected to conservation and preservation treatment.

In the central square, the team carried out primarily conservation work. Two stone benches standing by the north wall

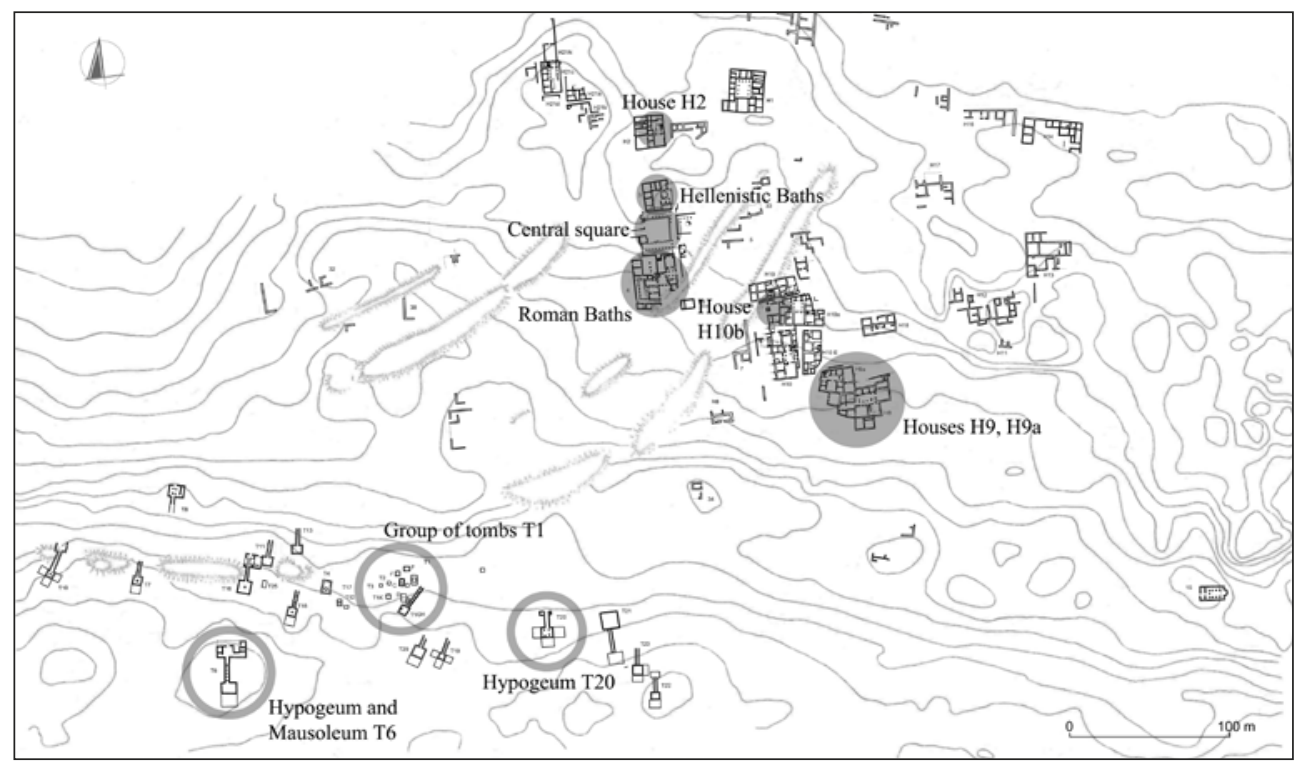

Fig. 1. Plan of Marina el-Alamein showing areas of work in the 2014 and 2015 seasons (PCMA Mission Archives) 


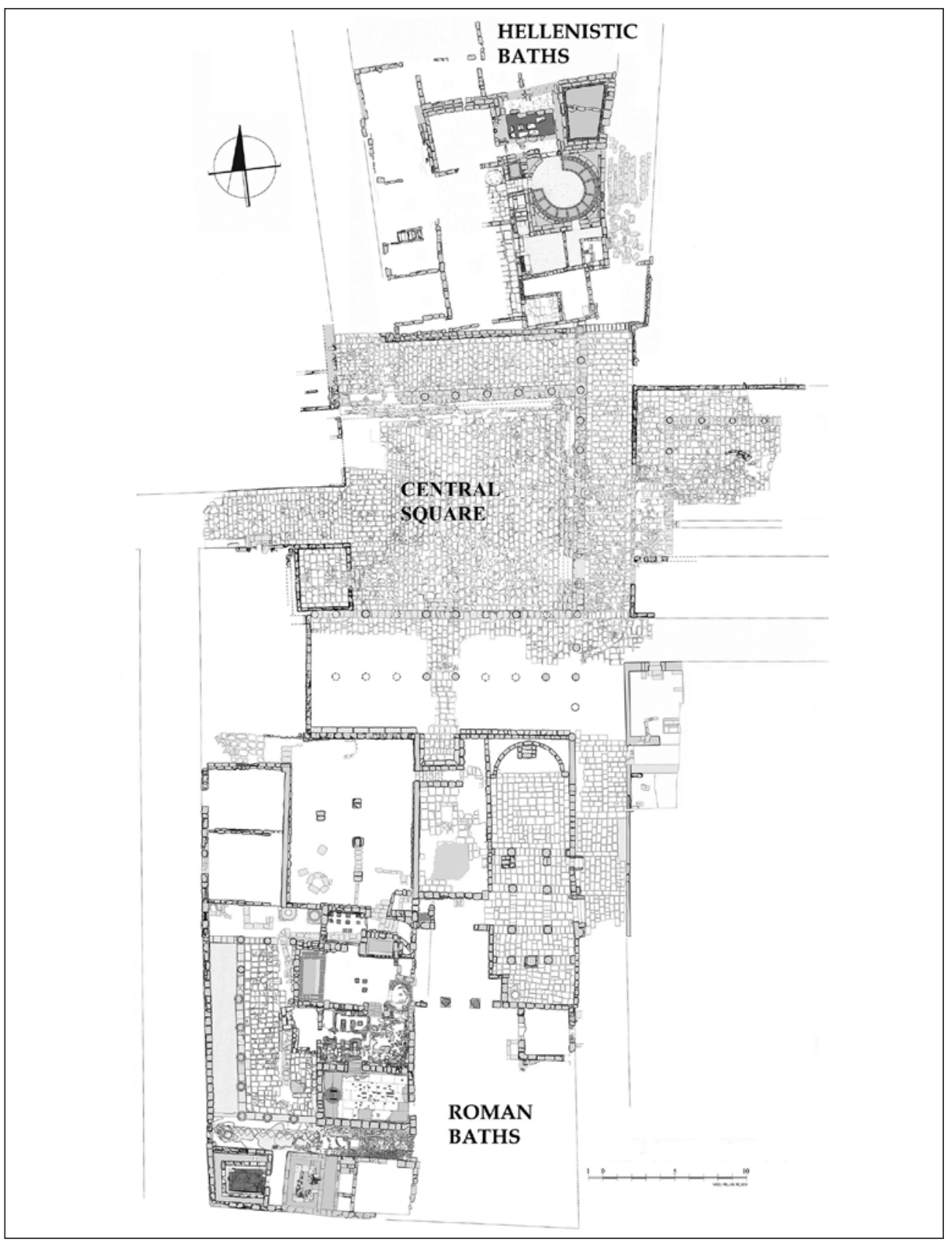

Fig. 2. The ancient town center with two groups of baths (compiled 2005-2015) (Drawing A. Btaszczyk, A. Brzozowska, R. Czerner, M. Krawczyk-Szczerbiniska) 
of the square and partly the wall itself were restored. Deteriorating shafts of three columns in the western part of the southern portico, and preserved lower parts of three columns in the eastern area of the same portico were protected by plastering. The lower parts of walls on both sides of the street turning to the east from the southeastern corner of the square were restored and partly reconstructed.

In line with preparations for the opening of the ancient town and the necropolis to visitors, the management of the site traced a short guided route that will be made available in the first stage of a visit. It includes several structures from the necropolis: relics of a large mausoleum connected to the hypogeum tomb T6, a group of monumental pillar tombs T1, T1F, T1J, T1K, T12, the hypogea $\mathrm{T} 20$ and $\mathrm{T} 1 \mathrm{GH}$, and the cluster of houses H9, H9a [Fig. 1]. Conservation of these structures had been carried out earlier at different stages of the project, sometimes quite distant in time. In 2015, the state of preservation of these structures was inspected and the necessary conservation work assessed. The tombs were found to be in good condition and ready to be

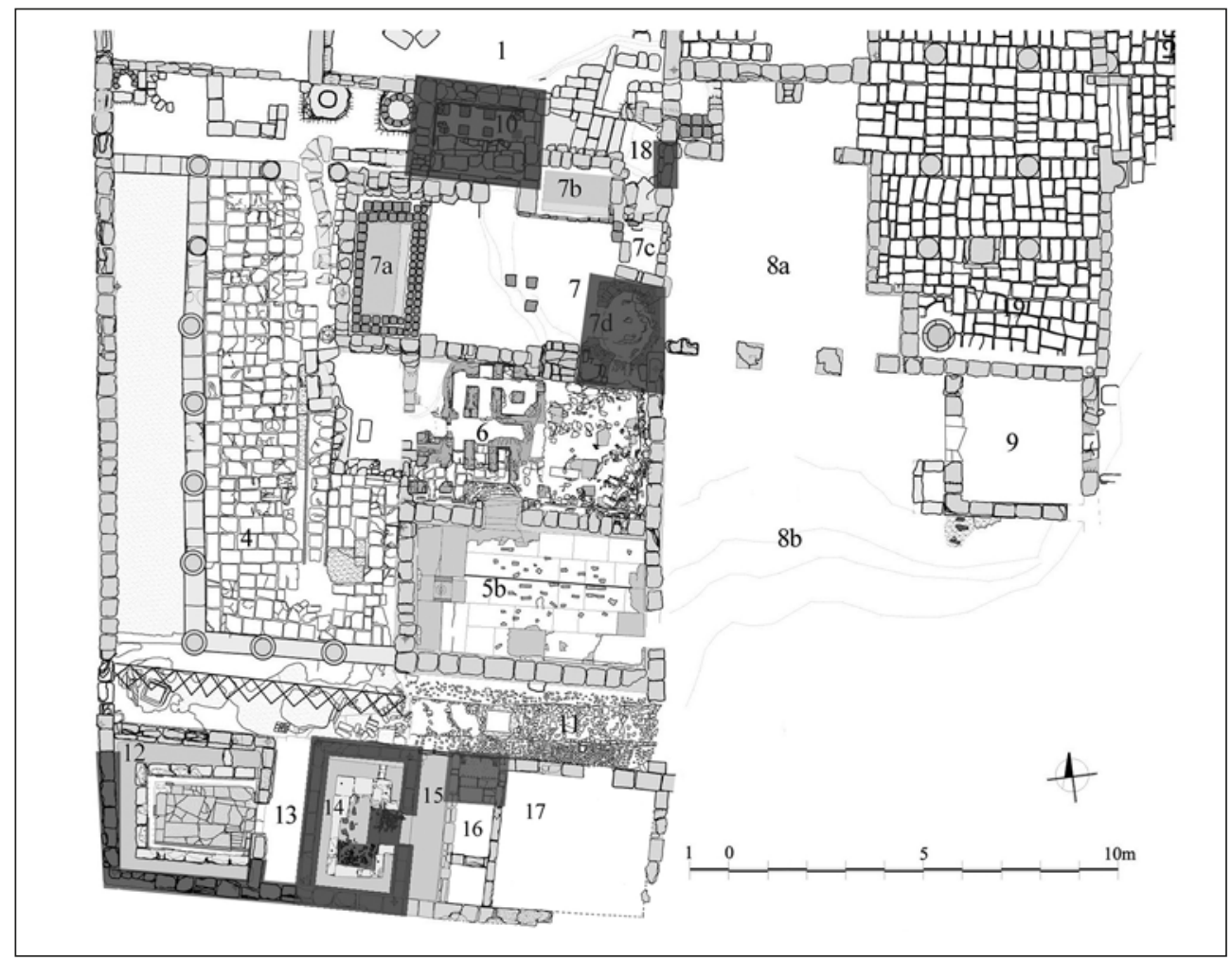

Fig. 3. Roman baths and civic basilica in Marina el-Alamein: plan showing areas of conservation work in 2014 and 2015 (Drawing A. Brzozowska, R. Czerner, M. Grzegorek, M. Krawczyk-Szczerbinska, K. Majdzik) 
opened to tourists at once, providing adequate organisation and safety measures. However, houses $\mathrm{H} 9$ and $\mathrm{H} 9 \mathrm{a}$, conserved in 1995-1999, required some treatment. Despite protection measures taken earlier, unfavorable weather conditions over the last 20 years resulted in further damage and losses, both in the walls preserved and in decorated architectural elements, especially in the columns of the courtyards. Over the years, such damage was noticed in other structures on the site; therefore their conservation has been ongoing and systematic. In 2015, conservation activities were intensified, especially in the above mentioned houses $\mathrm{H} 9$ and $\mathrm{H} 9 \mathrm{a}$, which are planned to be made available soon and whose deterioration is at the gravest. As far as the protection of columns is concerned, conservation was conducted also in other relevant places on site: houses $\mathrm{H} 2, \mathrm{H} 10 \mathrm{~b}$, and in the central square.

The team also continued studies of relics in the storerooms, and conservation treatment of the most valuable items, especially wall painting fragments and polychromed elements of architectural decoration.

A special task in the 2015 season was the organization of a jubilee exhibition on the occasion of the twentieth anniversary of the mission's activities. The exhibition entitled "20 years of the Egyptian-Polish Conservation Mission Marina el-Alamein" was prepared in cooperation with the Inter-Academy Institute of Conservation and Restoration of Works of Art, Poland. The exhibition was opened on 26 May 2015 at the Alexandria National Museum.

$[\mathrm{RC}]$

\section{SOUTHERN BATH}

The Roman baths and the civic basilica, situated together on the south side of the central town square [Figs 2, 3], have been the subject of research, architectural study and conservation work carried out by the Polish-Egyptian Conservation Mission since 2008. The most important rooms in the complex have been cleared and preserved, incuding a portico courtyard with partial anastylosis of the columns, and the main chambers: caldarium, tepidaria and monumental frigidarium, as well as the rooms in the southern area of the complex including a latrine. The general functional layout of the baths and many specific solutions were identified. Work continued in the 2014 and 2015 seasons.

\section{ARCHITECTURE}

The annex $(7 d)$ in the southeastern part of the caldarium is rectangular in plan. It is $1.83 \mathrm{~m}(\mathrm{E}-\mathrm{W})$ by $1.91 \mathrm{~m}(\mathrm{~N}-\mathrm{S})$. It lies above the praefurnium, approached from the east via an underground corridor, under the floor of the neighboring room (8a). The furnace was built of bricks and had the form of a tunnel covered with a barrel vault, running from east to west, the internal width being about $0.47 \mathrm{~m}$. It heated the hypocaust of room 7 . Annex $7 \mathrm{~d}$ was a part of this heating system [Fig. 4]. The brick structure of the annex was supported from below and encased the sides of a metal water-heating tank, which was probably situated in this spot. The tank was oval in plan, approximately $1.20 \mathrm{~m}$ 
(E-W) by $1.83 \mathrm{~m}(\mathrm{~N}-\mathrm{S})$; its impressed traces have survived. Bricks in the outer parts of the structure were bonded in lime mortar, whereas those in the furnace zone and immediately around and under the tank were bonded in clay mortar.

Rectangular room $10(2.36 \mathrm{~m}$ by $1.90 \mathrm{~m}$ ) neighbors the western part of the caldarium on the north [Fig. 5]. Its west wall runs along the line marked by the original west wall of the caldarium before its later extension westward. After the caldarium had been enlarged, access to room 10 was impeded. The chamber started to serve technical purposes, housing, in its southern part, a drain of

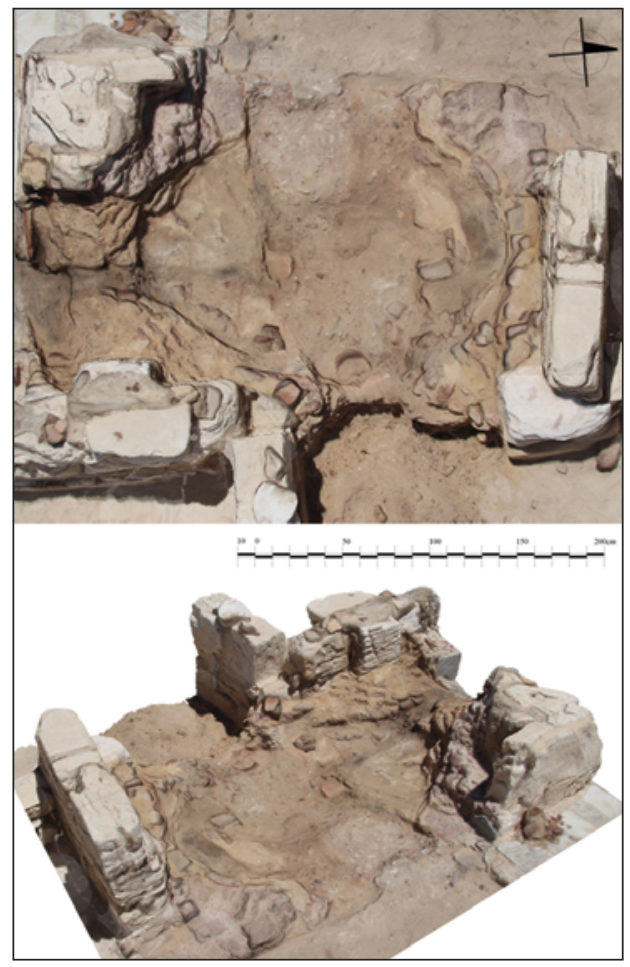

Fig. 4. Furnace in annex $7 d$ in the Southern Bath, top view and oblique view (Documentation M. Grzegorek) limestone slabs, carrying water off from the alveus (7b) situated to the east. It was established that room 10 used to be an integral part of the caldarium, perhaps not even separated from it by any wall, since it contained the same elements of hypocaust structure as in room 7: brick pilae and ceramic slabs lining the walls in the northern part. The flooring above the hypocaust in room 10 was later destroyed and its fragments used in an alteration of the structure that formed a substructure sloping west under the mentioned drain.

Several small rooms composed the southern part of the complex. These were identified in 2012 and 2013 as a latrine (12)

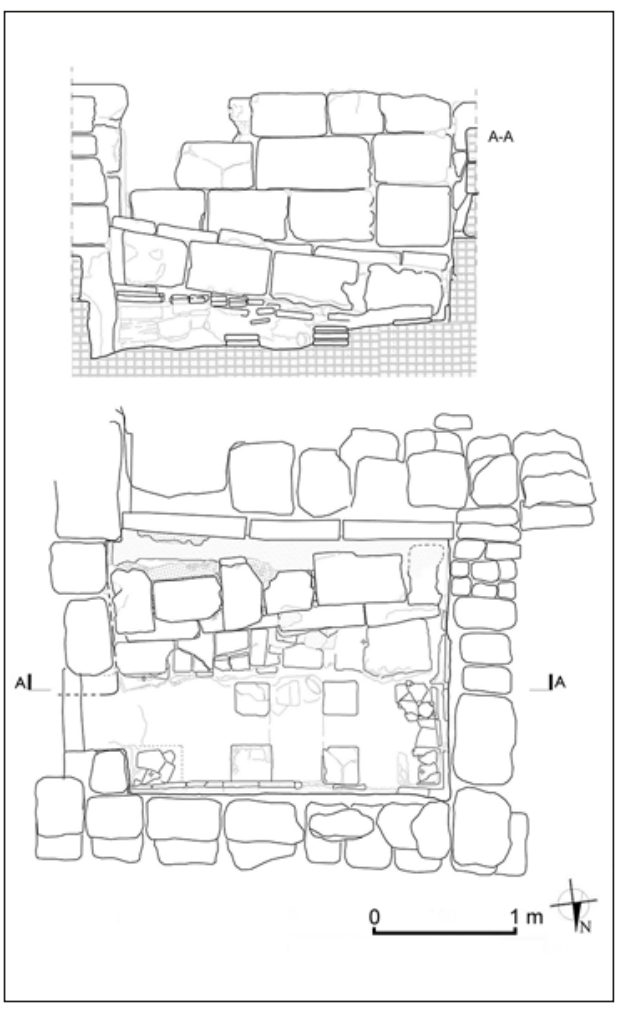

Fig. 5. Room 10 in the Southern Bath, plan and section (Drawing M. Grzegorek) 
and a corridor (13) on the west, leading to the latrine from the east. Research in chambers further to the east uncovered an analogous complex comprising a latrine (14), $3.53-3.60 \mathrm{~m}(\mathrm{~N}-\mathrm{S})$ by $2.17 \mathrm{~m}$, and its vestibule (15) in the form of a corridor of similar length $\mathrm{N}-\mathrm{S}$ and about $1 \mathrm{~m}$ wide [Fig. 6]. Both rooms had flooring made of small, irregular pieces of grey marble slabs. The drain encircled the latrine, with a gap for the entrance in the middle on the eastern side. Latrine seats were supported by long wooden beams, the ends of which rested in sockets in the walls and on setoffs. A low wall surrounding the drain bears traces of alterations on the northern and partly eastern side (see also in this volume, Koczorowska, Osiak, and Zambrzycki 2016: 189 and Fig. 3). Hidden under the flooring, the drain ran on the eastern side below the entrance to the room. Two openings in the northern wall of the latrine, connecting the drain with the sewer situated under the floor of the neighboring corridor 11 , served to supply and carry off flushing water.

Rooms 16 and 17 were partly uncovered. Narrow room 16 turned out to be a staircase with the first three steps made of stone blocks preserved in the northern part. Imprints of the elements fixing the door hinges were also preserved [Fig. 9].

[RC]

\section{ARCHAEOLOGICAL RESEARCH}

Conservation work was carried out under archaeological supervision.

Room 10. The room $(2.36 \mathrm{~m}$ by $1.90 \mathrm{~m}$ ) was investigated in 2012 (Czerner, Bąkowska-Czerner, and Majcherek 2015: 124-125); in the 2014 season, the hypocaust was excavated. Eight brick pilae (bricks $25 \mathrm{~cm}$ to the side; $2 \mathrm{~cm}$ thick) in two rows are visible in its northern part

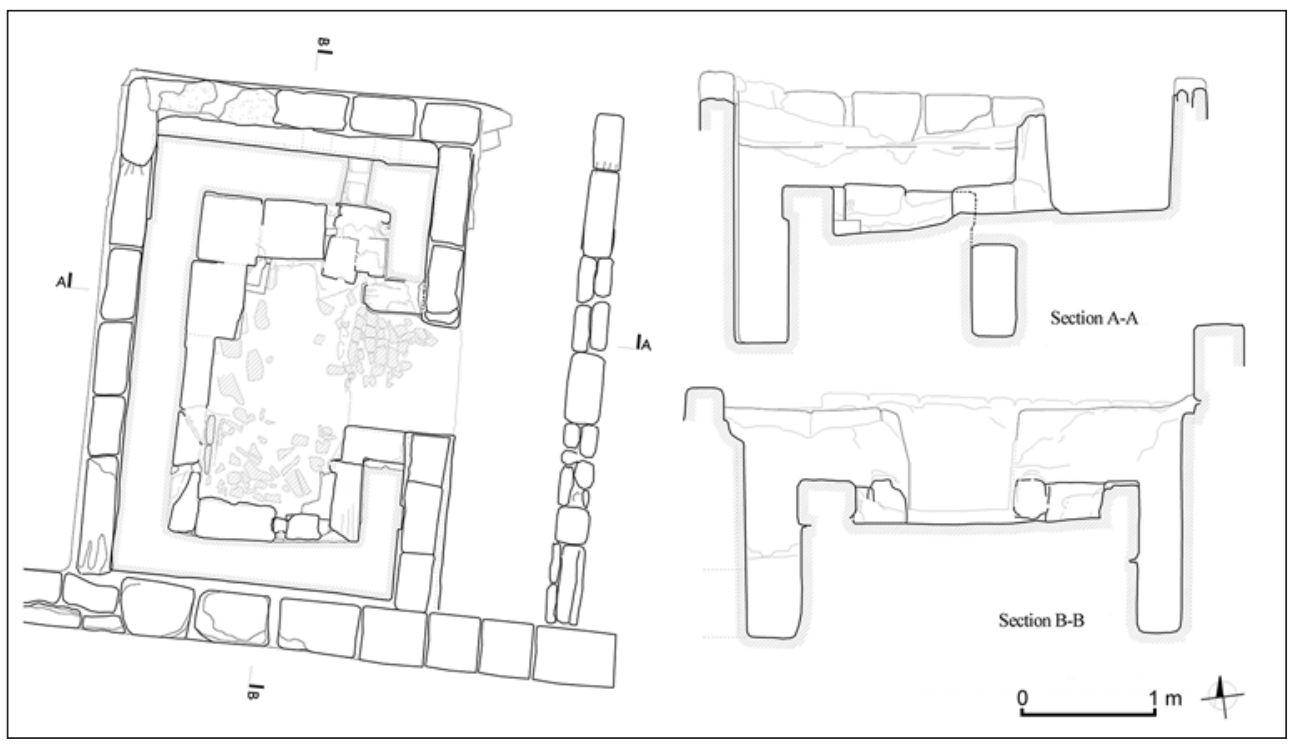

Fig. 6. Latrine (14) with vestibule (15) in the Southern Bath, plan and sections (Drawing M. Grzegorek) 
[Fig. 5]. Bricks adjoining the north and west walls have also survived, standing on the same level as the pilae stacks. In the southern part there is a drain. In 2014, one slab of the drain $(0.32 \mathrm{~m}$ by $0.20 \mathrm{~m})$ was raised and a lead pipe was found discharging water from the alveus (7b) in the caldarium (7) to the drain. The drain slopes sharply downwards to the west. In the western part it rests on original flooring, while in the eastern part pieces of damaged flooring were used to support the drain to achieve the slope. Three layers of flooring can be seen under it.

Room 7. Relics of the furnace $(7 \mathrm{~d}$; $1.91 \mathrm{~m}$ by $1.83 \mathrm{~m}$ ) were cleaned. It was built of baked bricks bonded with clay mortar. A brick vault was excavated on the east. Several fragments of blackened terracotta pipes used as flues were found.

Room 13. The wall tops of the room were excavated in 2012. It formed a corridor ( $3.78 \mathrm{~m}$ by $1.12 \mathrm{~m}$ ) leading to the western latrine (12). The walls, which stand $0.80-0.90 \mathrm{~m}$ high, turned out to be covered with polychromed plaster. In the 2014 season, the remains of plaster with paintings were described, protected with mortar bands and covered up. The painted decoration took on the form of vertical stripes of different colors and width, separated by black lines one centimeter wide. The original polychromy was coated with a layer of plaster.

Room 14. Partly excavated in 2013 (Czerner, Bąkowska-Czerner, and Majcherek 2015: 128), the room was now cleared completely $(3.53 \mathrm{~m}$ by $2.17 \mathrm{~m}$ ) [see Fig. 6]. It was identified as a latrine, the second one in this bath complex, somewhat smaller and made less carefully than the one discovered in the previous season (12) (Czerner, Bąkowska-Czerner, and Majcherek 2015: 126-127). In its east wall, a door opening $0.93 \mathrm{~m}$ wide and leading to a vestibule (15) was discovered. A drain emerged under a layer of sand and rubble. Big stone blocks, broken off from the walls, were found there. Pieces of painted plaster were found under the stone blocks of the southern drain. They were probably collapsed from the latrine walls. Below, in a layer of sand $0.30-0.40 \mathrm{~m}$ thick, there was a big pottery assemblage (including sherds from several amphorae and a fragment of a vessel filled with shells), as well as pieces of windowpanes and animal bones. At the bottom of the latrine lay a layer of dark sand about $0.10 \mathrm{~m}$ thick, mixed with heavily fragmented ceramics. The drain, $0.30-0.40 \mathrm{~m}$ wide and about $0.85-1.00 \mathrm{~m}$ below the latrine floor, was divided in its northern part by a stone wall that was $0.18 \mathrm{~m}$ wide; this repeated the situation from latrine (12) discovered in the earlier season. The wall separated two drain openings, $0.56 \mathrm{~m}$ by $0.20 \mathrm{~m}$, visible in the north wall. Fresh water was supplied to the latrine through the eastern drain, while sewage was carried off through the western one. The drain was observed to slope slightly from south to north. Its walls were covered with waterproof mortar. A socket approximately $0.30 \mathrm{~m}$ by $0.15 \mathrm{~m}$ was noted in the south wall above the drain, $1.40 \mathrm{~m}$ from its bottom. A seat would have been fixed there. A projection of the north wall (0.12-0.16 $\mathrm{m}$ wide) had the same purpose.

A layer of dark soil ( $0.10-0.12 \mathrm{~m}$ thick $)$ above the latrine floor $(1.87 \mathrm{~m}$ by $1.86 \mathrm{~m})$ yielded remains of a hearth as well as some small stones, fragments of marble tiles and baked bricks, not to mention a sizable assemblage of ceramics, a piece of plaster (the polychromy indicates that it came from corridor 13), the rim of a small bottle 
and animal bones. Beneath there was a layer of light packed sand with pieces of ceramics (the same layer was observed in corridor 15).

The flooring made of irregular grey marble tiles survived only in the southern part and in the passage from the vestibule (15). Stones lining the edge of the drain to the north and in the northwestern corner were much bigger than the rest. A fragment of a rectangular vessel of stone can be seen under them. Ceramics found in

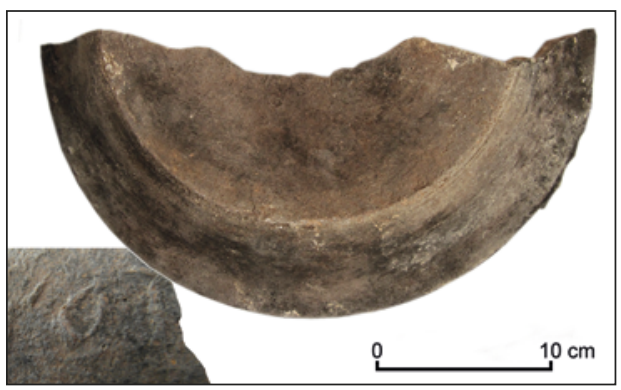

Fig. 8. Fragment of a frying pan with a stamped inscription on the bottom (close-up at bottom left) (Photo G. Bakowska-Czerner) the latrine come from the 2 nd century AD (G. Majcherek, personal communication).

Room 15. This is a vestibule, 0.93/ $0.98 \mathrm{~m}$ wide and $3.68 \mathrm{~m}$ long, leading from the courtyard to the latrine (14). Glasses and pottery were found in a layer of hard sand. In the southern part of the corridor, a stone partition was observed before the entrance to the latrine, setting off a space measuring $1.10 \mathrm{~m}$ by $0.93 \mathrm{~m}$.

Three kitchen vessels, partly preserved, were found in a layer of compacted soil, greasy to the touch, with traces of a hearth. The finds included fragments of a jug with trefoil rim and cooking pots [Fig. 7] as well as half of a frying pan with an inscription [Fig. 8], pieces of a lamp and sherds of amphorae, animal bones, a fragment of fish skeleton and eggshells. A flooring made of irregular pieces of grey marble tiles, just like in the latrine, was found here. It was covered with a layer of sand $0.10 \mathrm{~m}$ thick, containing potsherds. A structure $0.35 \mathrm{~m}$ high stood on it. In the northern part of the corridor, a layer of sand ( $0.20 \mathrm{~m}$ thick)

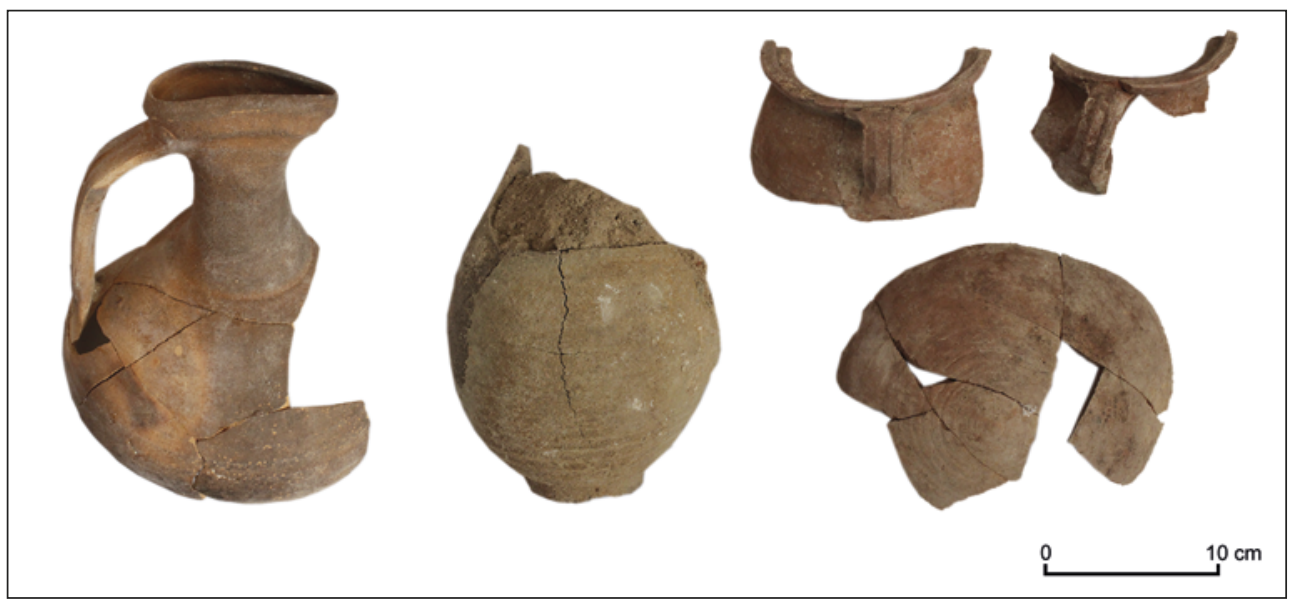

Fig. 7. Kitchen vessels from corridor 15

(Photos G. Bąkowska-Czerner) 
corresponded to the silty soil deposit in the other part. Below it was a layer of compacted sand with ceramics. Several surviving layers of plaster on the walls of the corridor (0.75-0.90 m high) included two layers of waterproof plaster. Pottery found in the room is dated to the 2 nd century AD (G. Majcherek, personal communication).

Stratification in rooms 14 and 15 suggests that they were reused at the same time. Small hearths were installed and the corridor partitioned without damaging the plastered walls.

Room 16. Wall tops were unearthed to a depth of $0.25 / 0.26 \mathrm{~m}$. The room was divided by a wall into a smaller southern part measuring $1.10 \mathrm{~m}$ by $0.98 \mathrm{~m}$, and a bigger northern one sized $1.10 \mathrm{~m}$ by $1.30 \mathrm{~m}$. A stairway, $0.90 \mathrm{~m}$ wide and $0.77 \mathrm{~m}$ high, was installed in the northern part [Fig. 9]. There were three steps leading upstairs (the bottom one did not survive) and a door that gave onto it. Remains of jambs have survived. Rooms south of the stairway remained unexplored.

Room 17. Wall tops appearing under a layer of clean sand and stone blocks set off a room sized $3.84 \mathrm{~m}$ by $3.49 \mathrm{~m}$. The south and east walls at this height were still poorly visible. Traces of a hearth were noted under a layer of compacted sand, $0.20 \mathrm{~m}$ thick, in the northwestern corner and along the west wall. Blackening is visible on the north and west wall. Fragments of vessels, including kitchenware, and animal bones, as well as a the top end of a bronze nail were found in this layer. A bronze coin, a small glass ball, a bone spatula, and several fragments of lamps were also discovered. Fragments of glassware and windowpanes appeared, too. The finds are dated to the 2nd century and beginning of the $3 \mathrm{rd}$ century AD (R. Kucharczyk, personal communication). The layer is situated about $0.20-0.25 \mathrm{~m}$ above the level of the floor in

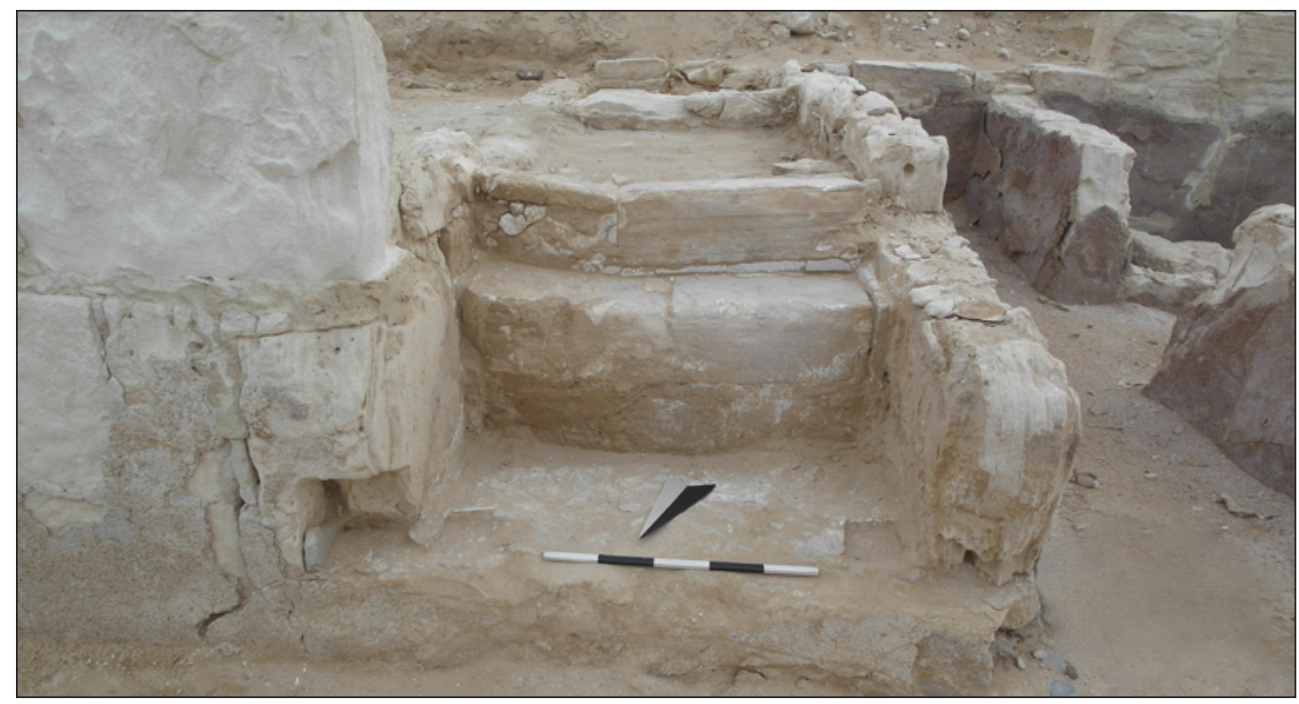

Fig. 9. Entrance and stairs 16 in the Southern Bath (Photo R. Czerner) 
the neighboring corridor, which resembles the situation from the previous season in nearby rooms (14 and 15).

Surface. Eight bronze coins and several pieces of bronze nails were found next to the central square in 2014. Five other badly weathered bronze coins were found in 2015.

$[\mathrm{GB}-\mathrm{C}]$

\section{NOTE ON THE POTTERY}

Pottery finds, although rather limited in number, seem to be largely similar to those already presented in earlier reports (Czerner, Bąkowska-Czerner, and Majcherek 2015). Most of them were discovered in non-stratified contexts, such as fill layers or dumps, throughout the southern wing of the baths (rooms 1417), with only some of them originating from undisturbed contexts. Dating of the ceramics recorded there, corresponds to the general dating of the excavated structures.

Contexts explored in the latrine (14) and its vestibule (15), were especially prolific, making for most of the finds. Common wares account for a major part of all recorded assemblages, arriving at almost 95-97\% of the sherd count. Such a high ratio is not unusual however, as shown by intra-site comparison. It is noteworthy that quite a number of sherds show signs of transportation, evidenced by a high degree of fragmentation, rounded edges and abraded surfaces; they could well have originated from elsewhere. Traces of feces on a few sherds suggest that they had been used as pesso $i$ in the latrine.

To sum up, the most obvious feature of all the groups analyzed is the uniformity of their composition. The bulk of commercial amphora sherds represents regional products, mostly the "bitronconical"
AE3 class produced in the Mareotis region. Occasional fragments of tall, cylindrical pseudo-Koan AE4 amphorae, manufactured in the same region, were also attested (Dixneuf 2011: 129-133, Figs 113-116). In turn, quite a large group of AE3 vessels could be assigned to the northwestern coastal zone, where a number of production sites was identified (Rieger and Möller 2011; Majcherek and Shennawi 1992). All these amphorae were apparently intended for wine transportation. Both Mareotis and the whole coast with its moderate Mediterranean climate emerge as intensive wine production regions. This view is supported not only by historic sources, but also by archaeological evidence. Surveys conducted there in recent years have revealed a large number of wineries, commonly recorded not only around the Mareotic Lake but also in Marmarica. In both regions, wine cultivation appears to have been a dominant agricultural activity, with farming of cereals, vegetables, figs, olives and livestock breeding lagging behind (Rieger and Möller 2011).

Imported transport amphorae include mostly the "pinched handle" amphorae (Mau 27/28, Agora G199). Several fabric varieties: buff, red and red-micaceous, sometimes covered with creamy wash, representing Cilician and Cypriot manufacturers, were identified in almost every context throughout the bath. This type of middle-sized amphora with its cylindrical body and characteristic mushroom-like toe, is undoubtedly the most abundant foreign vessel type at the site. The surprising profusion of these amphorae contrasts sharply with other Egyptian Greco-Roman sites, where their reported presence is rather rare. Coupled with the overwhelming presence of Cypriot 


\section{EGYPT}

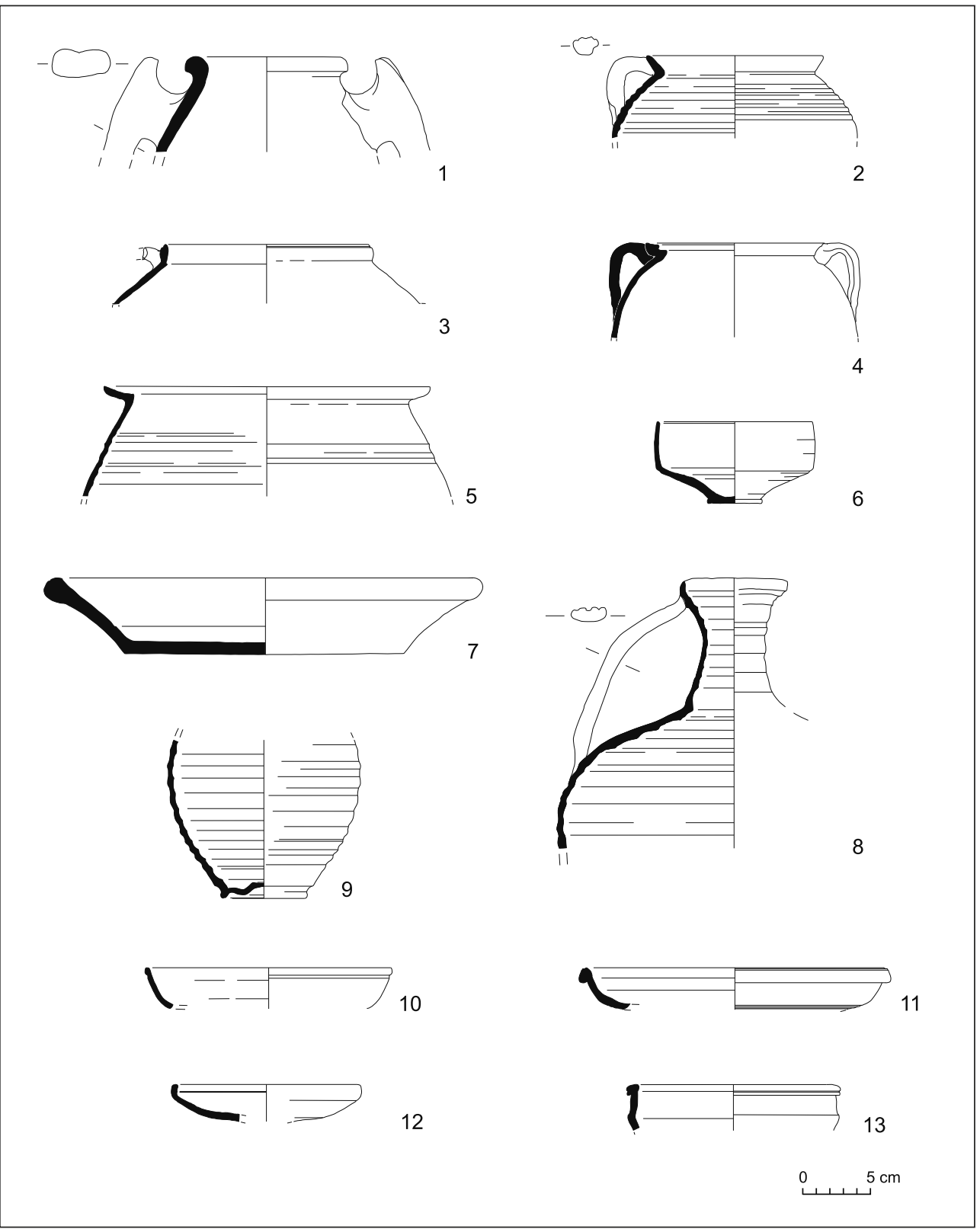

Fig. 10. Selected pottery finds: 1 - pseudo-Cos-en-cloche (Agora M54) amphora; 2 - local cooking pot; 3 - Aegean cooking pot; 4-Egyptian Nile silt cooking pot; 5-imported cooking pot; 6 - local imitation of a pareti sottili bowl; 7 - frying pan; 8-9-imported jugs; 10-13-Cypriot sigillata tableware bowls P26 (10), P11 (11), P29 (12), P40 (13) (Drawing G. Majcherek) 
Sigillata, this provides further evidence for special trade relations between the Marina settlement and Cyprus and Cilicia.

Imports from the East are generally well attested. "Pinched handle" amphorae are not the only vessels to confirm importation of Cilician wine and oil at the site. Alongside the familiar "pseudo-Cosen-cloche" (Agora M54) [Fig. 10:1], the excavation recorded several fragments of Pompei V amphorae. Vessels from Crete are particularly well represented, although mostly as assorted body sherds, with few specific rims that can be identified as Crétoise 1 and 2 types (Majcherek 2007). Their production and exportation peak, in the mid 1st through mid 2nd century $\mathrm{AD}$, falls conveniently into the general chronological horizon of the site. Some Knidian and Dressel 5 "peaked handle" amphorae complete the repertoire of Aegean imports. It is surprising however, that none of the early Gaza-Ashkelon containers have been recorded while analysing various assemblages from the baths. Western amphorae are, on the other hand, very rare and limited to occasional fragments of Tripolitanian vessels.

Household wares, regularly found throughout the baths, are the second most numerous group, although their relation to the primary bath function is hard to specify. Their presence there could be coincidental. A few fragments of cooking pots were retrieved from the latrine channel (14), while others were found in the vestibule (15) and adjacent room 17. It is quite probable though, that all these pots could have been reused as toilet vessels in the latrine. Some of these cooking vessels were made of conspicuous alluvial clay fabric [Fig. 10:2], while others were positively identified as products from the northwestern coast. All represent a similar form: globular body, rather heavily ribbed, with two small strap handles and reverted, otherwise plain rim. Some vessels of Aegean origin were also recognized in the assemblages. They are usually larger, with plain, upright rim, sometimes grooved on top [Fig. 10:3]. All have globular, slightly sagging carinated bodies with two small handles attached under the rim. All these examples belong to the 1 st -2 nd centuries AD series. However, some earlier vessels made from Egyptian (Nile silt) fabric, given a folded lip apparently intended to be topped with a lid, were also recorded [Figs 7 top right; 10:4]. Although usually dated to the early 1 st century $\mathrm{AD}$, their manufacturing tradition goes back to the Late Hellenistic period. Several similarly dated splayedout plain rims of imported, thinwalled pots were also found [Fig. 10:5]. Surprisingly many examples of fine alluvial fabric bowls, closely imitating imported pareti sottili bowls on low solid foot, were also found in the channel [Fig. 10:6]. Meriting particular note, however, is a specimen of imported (Aegean?) flat-based frying pan (from room 15), with standard thickened rim [Figs 8; 10:7]. On its underside, there is a partly preserved stamp with indistinct Greek lettering (probably retrograde) in raised relief: .]TOY. Similar stamps have been recorded in, among others, Berenike-Benghazi, particularly in the early 2 nd century $\mathrm{AD}$ context (Riley 1979: 253-256). Frying pans of this type had wide distribution in the eastern Mediterranean, including Egypt, although stamped examples are rather rare in Marina. So far, three have been recorded (Łajtar 2001: 65-66). 
Closed vessels, although scarce, were also present in the assemblage. They include an imported Aegean jug with trefoil mouth [Figs 7 left; 10:8], and some ribbed marly clay jugs on ring bases, most probably originating from the Marmarica [Figs 7 bottom right; 10:9].

While plain wares were dated generally to the 1 st $-3 \mathrm{rd}$ centuries $\mathrm{AD}$, providing a rather vague chronological horizon, the table wares offerred a somehow more refined chronology. A dozen or so fragments of Cypriot Sigillata rims and bases should be listed, spanning a rather wide chronological range. The record comprises occasional fragments of bowls P26 (Hayes 1985: P26) [Fig. 10:10], dated to the second half of the 1 st century $\mathrm{AD}$ and so earlier in the series, and of the slightly later bowls P11 [Fig. 10:11], produced until the first half of the 2 nd century AD. The former, found in vestibule 15, although generally corresponding chronologically to some of the plain ware forms [Fig. 10:4-5] listed above, should be seen most probably as residual.

The 2 nd century AD horizon is much better evidenced. A few fragments of P29 bowl [Fig. 10:12] and the omnipresent crater with everted double-lip rim (form P40) [Fig. 10:13], dated to the first half of the second century AD (Hayes 1985: 86-88), are traditionally the most common, evidenced by a significant number of fragments. Some Egyptian made small-sized imitations of this bowl were also identified. Both forms, rather common at the site, are also quite frequent on other Egyptian sites (for Eastern Desert and Red Sea sites, see Tomber 2006).

[GM]

\section{FUNCTIONAL LAYOUT OF THE BATH}

Findings regarding the functioning of such small balnea (Nielsen 1990: 3) with the main rooms arranged in a row-type layout (Krencker et al. 1929: Figs 234-240; Nielsen 1990: 87) remain generally relevant in the light of the current archaeological work [see Fig. 3]. Water reservoirs were placed on an elevated substructure located on the northern side, a utility courtyard (1) being located next to them. A complex, consisting of rooms 7-6-5, arranged in a row in the middle of the baths, together with a spacious hall, made out of two connected rooms 8 and $8 \mathrm{a}$, closing off the baths from the east, formed a functional row comprising a caldarium, probably two tepidaria and a frigidarium. A courtyard (4) with three porticoes was situated on the west side of the complex. A complex of small rooms (12-17) lay south of the courtyard and corridor (11), leading from it to the east. It included an elegant latrine (12). The 2014 and 2015 discoveries and studies contributed new, detailed information to the above-mentioned outline, concerning elements of the caldarium and the southern part of the complex.

The function of annex $7 \mathrm{~d}$, which was sectioned off in the southeastern part of the caldarium (7) in the second phase of the operation of the complex, was clarified [see Fig. 4]. The annex was built of red bricks above the location of a praefurnium from the second phase. The results of research in 2014 showed that a metal water-heating tank was probably placed here, directly above the praefurnium proper, thus making it one structure.

Relics of a hypocaust were unearthed in room 10 [see Fig. 5]. Situated behind 
Rafał Czerner, Grażyna Bąkowska-Czerner, Wiesław Grzegorek, Grzegorz Majcherek EGYPT

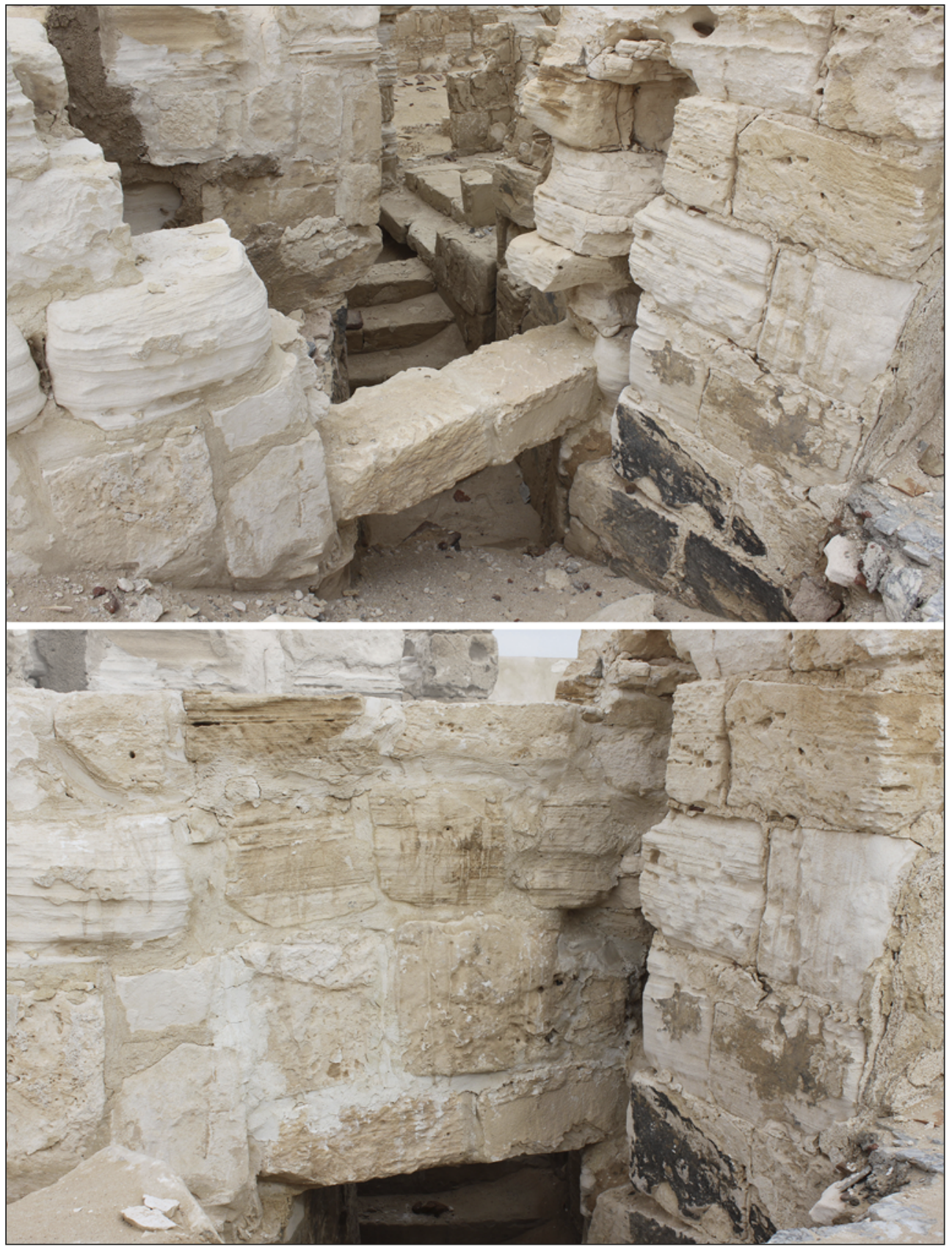

Fig. 11. Southern Bath. Wall above the passage to the underground corridor (between rooms 18 and 8a), before and after continued restoration in 2014 (Photos R. Czerner) 
the north wall of the caldarium (7), west of the alveus $7 \mathrm{~b}$, the room ceased to be used in the second phase, and then a drain, carrying water from this alveus, was built on its floor. However, in the original phase the room was clearly part of the caldarium, which was obviously bigger at that time.

Rooms 12 and 13, discovered in 2012 and 2013 in the southern part of the baths, functioned as a latrine and vestibule. In the discussed seasons, another similar complex was unearthed to the east: a latrine (14) and an entrance corridor (15) [see Fig. 6]. Rooms further to the east, that is, chamber 16 and the ones beyond it, only partly examined so far, must have had similar functions.

$[\mathrm{RC}]$

\section{CONSERVATION WORK}

In the 2014 season, conservation and construction work was carried out in rooms $7 \mathrm{a}, \mathrm{b}, \mathrm{d}, 8 \mathrm{a}, 10,12-15$ of the Southern Bath [see Fig. 3]. In 2015, additional intervention work was carried out on structures conserved in previous years, namely in rooms $6,7,7 \mathrm{a}, 7 \mathrm{~b}$ and the latrines, i.e., rooms 12-15.

Relics of a brick structure (7d) once encasing the water-heating tank were conserved and reinforced. The outer brick parts, originally built using lime mortar, were partly filled in and thus made slightly higher. This also enabled rainwater to flow away from the surface, providing at the same time a casing for the rest of the relic (built with clay mortar), which was covered with geotextile and covered with sand.

An exceptional conservation risk was posed by remains of a wall hanging over the passage to the underground corridor (18) [Fig. 11]. The wall separates the back of the caldarium from the northwestern part of room 8a. After dismantling the upper parts of the wall, which had been in danger of collapse for some time, a supporting structure was constructed in 2013. It was composed of two reinforced concrete beams which formed a lintel above the passage and was hidden in hollows cut in the bottom of stone blocks laid on top of them. There was no lintel beam above the passage at the time that it was first pierced in the wall, hence the need to hide the new lintel securing the reconstructed part of the wall. In 2014, the next four layers of solid blocks were laid on top of the reconstructed wall.

The relics of the hypocaust discovered in room 10 were reinforced, then covered with geotextile and reburied with sand.

The most interesting rooms in the bath complex that underwent conservation in 2014 were rooms 14 and 15, incorporating a latrine and a narrow corridor leading to it. Marble flooring which has survived in good condition in both interiors, as well as elements of the latrine drain casing, may become appealing display items in the future. Some preservation and partial reconstruction of this flooring were required. Protective bands were also put on the edges of the remains of plaster which had started to peel, while the joints on the remaining parts of the walls were filled with mortar. Some sections of the walls, separating rooms $12-15$, and the outer walls of the bath complex west and south of rooms 12-14 were topped with one new layer of original blocks. This protects the complex of two latrines relics from being covered up by sand.

The mortar used for masonry work had the following proportions: sand/lime/ white cement 3:2:1. 


\section{CENTRAL TOWN SQUARE CONSERVATION AND PROTECTION}

Conservation and protection work within the central square of the ancient town of today's Marina el-Alamein, tentatively identified as the forum (Daszewski et al. 2005: 86-92), has been carried out since 2006. It has included anastylosis up to a considerable height of the eastern half of the south wall in the south portico of the square, restoration of stone benches standing by that wall and in an exedra in the middle of the portico, and anastylosis of several columns, four of them to full height. In 2014 and 2015, eroding shafts of columns were protected (by pointing and partial plastering), as well as parts of the walls in the southeastern corner of the square. The walls and stone benches of the north portico of the square were also restored.

The portico wall on the north side of the square was preserved and partly reconstructed (to a height of five layers at the most) using original stone blocks. Restoration of two collapsed stone benches, standing by that wall, was also carried out. Made of limestone slabs, the benches were supported by carved legs set $1.10-1.20 \mathrm{~m}$ apart. Two of the legs, which had suffered the greatest damage, were replaced with reconstructed ones. Two layers were also added on the top of a shaft of a corner column adjoining the portico wall and the benches. The northern part of the wall on the east side of the square was restored and partly reconstructed as well (for more details of this project, see below, Koczorowska, Osiak, and Zambrzycki 2016: especially Fig. 1, in this volume).

[RC]
Numerous, closely spaced quake-related displacements can be seen in the north wall of the square. Some gaps are up to $8 \mathrm{~cm}$ wide. The position of the displacements was maintained while laying the upper part of the wall. The entrance in the east wall of the northern portico was cleaned and the upper parts of the wall with jambs were reconstructed.

In the southeastern corner of the central square, stone blocks in the first bottom layer of the wall corner were replaced, and one more layer was added above them.

On the south side of the street running from the central square to

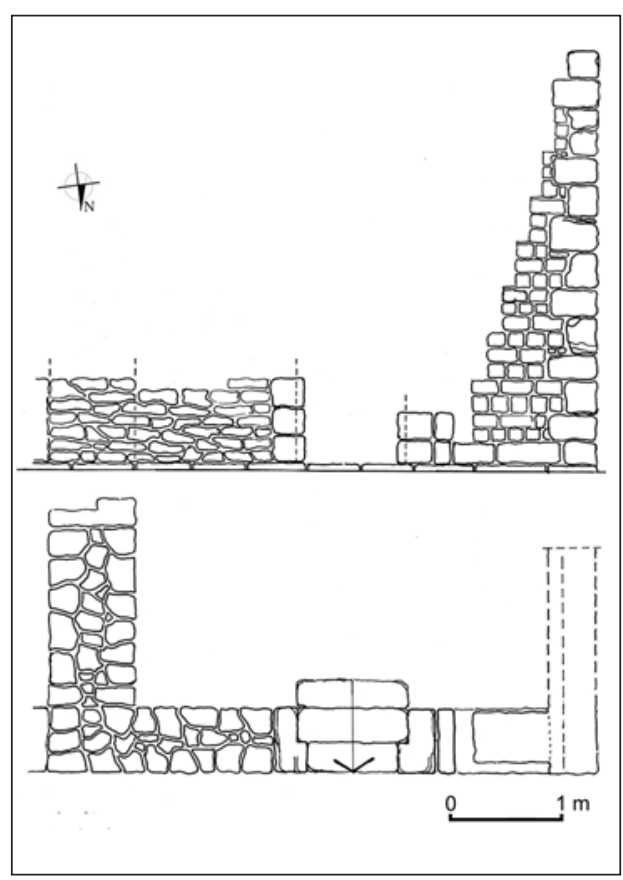

Fig. 12. Restoration of a house facade (Drawing W. Grzegorek) 
the east, the eastern jambs of a door opening were reconstructed, using the original components. An adjoining wall, $0.73 \mathrm{~m}$ high, $0.60 \mathrm{~m}$ wide, and $1.97 \mathrm{~m}$ long, was built of crushed rock gravel. It runs, to the east, towards the corner, and about $1.50 \mathrm{~m}$ further to the south [Fig. 12].

Losses in the side surfaces of three columns in the western part of the southern portico were also filled in with mortar.

[WG]

\section{DETERIORATING WALL AND COLUMN CONSERVATION AND PROTECTION}

Inspection of the state of preservation and repair of walls of rubble masonry in houses $\mathrm{H} 9$ and $\mathrm{H} 9 \mathrm{a}$ were carried out in 2015. The original conservation from 1995 through 1999 had suffered considerably from unfavorable weather conditions on site. Winter rain tends to erode limestone as well as mortar in the wall joints in the basal zone up to a height of $20-40 \mathrm{~cm}$, resulting in the mortar and stones being worn away in most of the walls and in the collapse of some parts of the walls.

In rooms 12, 13, 14, 15 and the courtyard of house $\mathrm{H} 9$, and 11,12 and 14

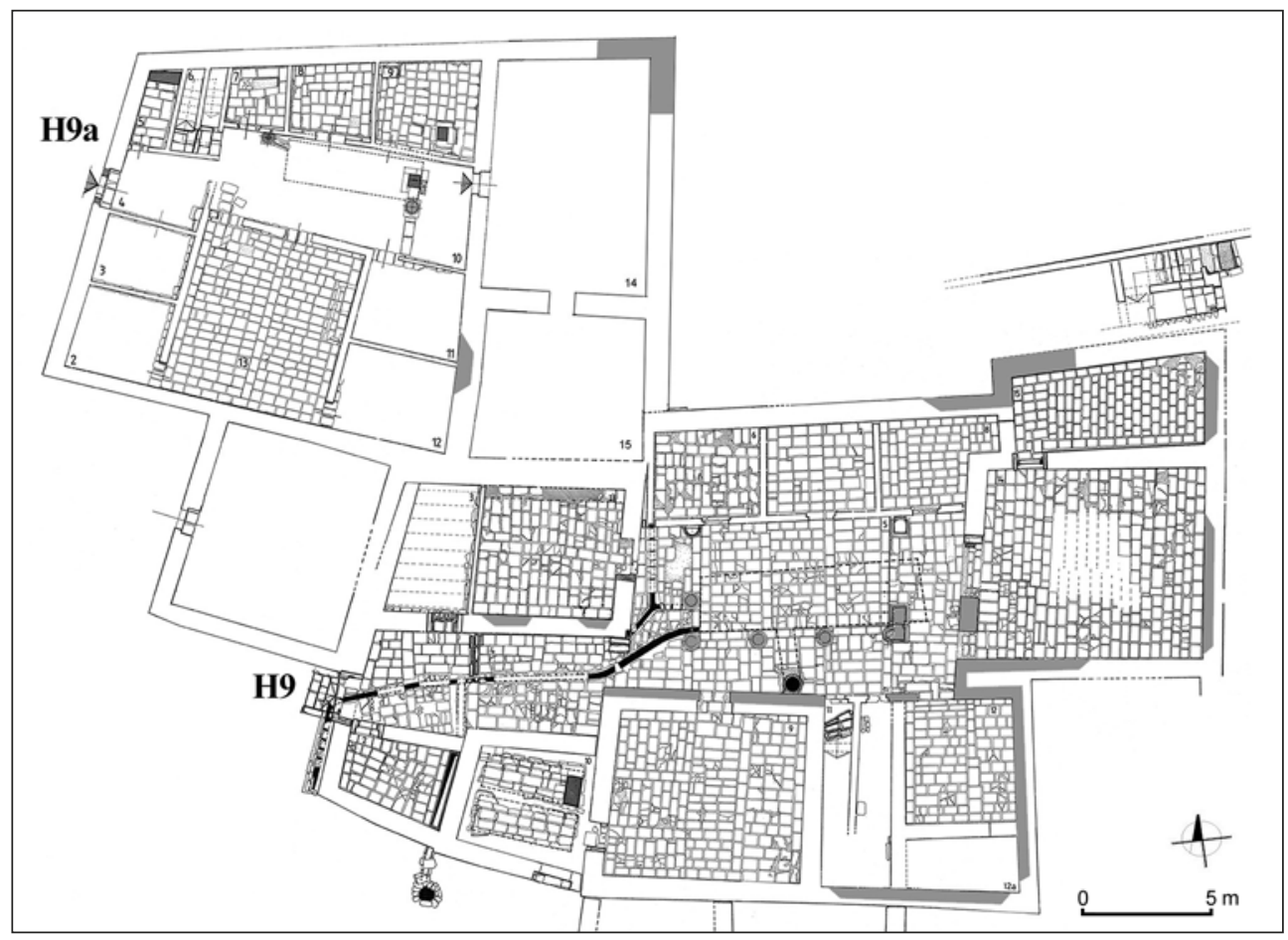

Fig. 13. Plan of houses H9, H9a showing areas where conservation activities were undertaken in 2015 (Drawing R. Czerner, S. Medeksza) 
of house $\mathrm{H} 9 \mathrm{a}$ (as well as in the area of the northern and southern baths), masonry and plastering protection work was carried out, filling in crevices in the rubble masonry and joints [Fig. 13]. Places where the stones had fallen out or disintegrated were cleaned thoroughly, saturated with water, and the joints filled in, layer by layer, with cement-lime mortar made on the basis of white cement. Losses were then filled in, the stones replaced, or new layers of walls built using stones of suitable sizes found in the vicinity [Fig. 14]. Care was taken to fill joints properly and lay the blocks patinated surface out.

Severe rain and wind also caused losses of mortar in the joints between the drums of unplastered columns. Many stone drums

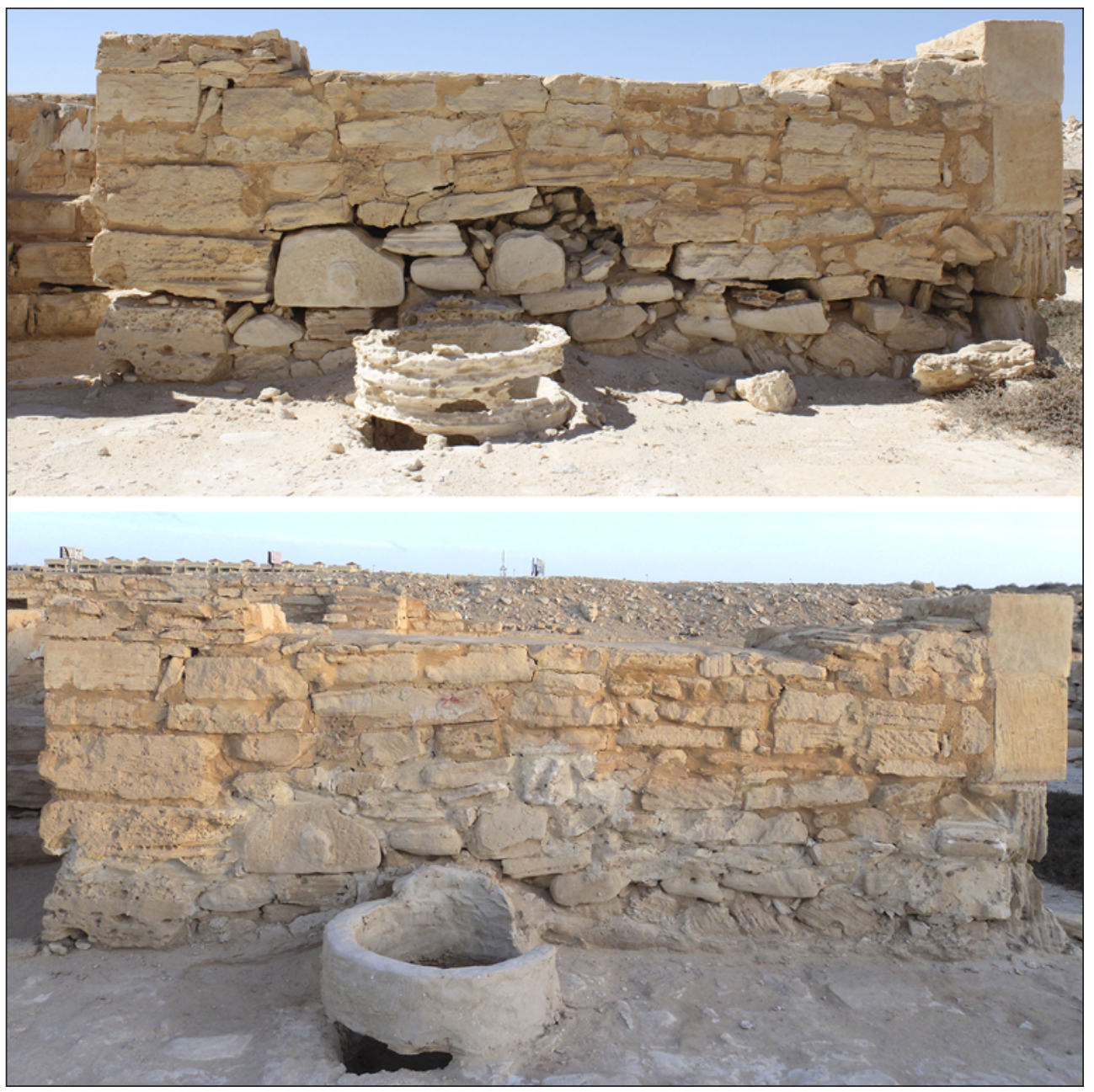

Fig. 14. Courtyard wall in house H9 before and after conservation, exemplifying the scope of maintenance repairs (Photos R. Czerner, W. Grzegorek) 
eroded: stones on their outside became powdered resulting in deep losses. Decay was due also to the poor quality of ancient building material. Similar processes had taken place already during the construction and functioning of the ancient town. Periodic repairs are necessary, as much then as now.

Damage of the type described above was best visible in the columns of the courtyards in houses $\mathrm{H} 2, \mathrm{H} 9, \mathrm{H} 10 \mathrm{~b}$ and in the main town square. Damaged joints and fragments of stone column drums were filled in with mortar. In the case of more damaged lower parts of columns, they were plastered as was the practice in antiquity, thus protecting the stone from unfavorable environmental conditions.

The cement-lime mortar used for all the plastering and bricklaying was made on the basis of white Portland cement in the following proportions: 6 parts sand : 3 parts lime : 1 part cement.

[WG]

\author{
Prof. Rafał Czerner \\ Wrocław University of Science and Technology, Faculty of Architecture \\ 50-317 Wrocław, Poland, ul. Bolesława Prusa 53/55 \\ rafal.czerner@pwr.edu.pl \\ Dr. Grażyna Bąkowska-Czerner \\ Jagiellonian University, Center for Comparative Studies of Civilizations \\ 31-044 Kraków, Poland, ul. Grodzka 52 \\ grazyna.bakowska-czerner@uj.edu.pl \\ Wiesław Grzegorek \\ wieslawgrzegorek@wp.pl \\ Dr. Grzegorz Majcherek \\ Polish Centre of Mediterranean Archaeology, University of Warsaw \\ 00-497 Warsaw, Poland, ul. Nowy Świat 4 \\ grzegorz.majcherek@uw.edu.pl
}

\title{
REFERENCES
}

Czerner, R., Bąkowska-Czerner, G., Grzegorek, W., and Majcherek, G. (2016). Research and conservation in Marina el-Alamein in 2014 and 2015 (Polish-Egyptian Conservation Mission). Part two: the Hellenistic baths. PAM, 25, 167-184

Czerner, R., Bąkowska-Czerner, G., and Majcherek, G. (2015). Research and conservation in the Roman baths of Marina el-Alamein in the 2012 and 2013 seasons (Polish-Egyptian Conservation Mission). PAM, 24/1, 113-138

Daszewski, W.A. (1991). Marina El Alamein - the site of an unknown Graeco-Roman settlement on the Mediterranean coast of Egypt. In W.A. Daszewski, W. Bentkowski, U. Fidecka, A. Sawecki, J. Radzik, Z. Sztetyłło, and G. Majcherek, Marina El Alamein: Archaeological background and conservation problems. The Polish-Egyptian Preservation Mission at Marina, 1988. The Polish Excavation Mission at Marina, 1987-1989, I [=Reports of the Research-Conservation Mission of PKZ 18] (pp. 7-18). Warsaw: State Enterprise, the Ateliers for Conservation of Cultural Property (PKZ) 
Daszewski, W.A. (1995). Témoignage de l'urbanisation de la côte méditerranéenne de l'Égypte à l'époque hellénistique et romaine à la lumière des fouilles de Marina el-Alamein. BSFE, $132,11-29$

Daszewski, W.A. (2011). Graeco-Roman town and necropolis in Marina el-Alamein. PAM, 20, 421-456

Daszewski, W.A. in collaboration with I. Zych, G. Bąkowska, and A. Błaszczyk (2007). Marina el-Alamein. Excavation report, 2005. PAM, 17, 75-97

Dixneuf, D. (2011). Amphores égyptiennes: production, typologie, contenu et diffusion, III siècle avant J.-C-IX siècle après J.-C [=Études Alexandrines 22]. Alexandria: Centre d'études alexandrines

Fournet, T., Lucore, S.K., Redon, B., and Trümper, M. (2013). Catalog. In S.K. Lucore and M. Trümper (eds), Greek baths and bathing culture: New discoveries and approaches [=BABESCH Supplement 23] (pp. 269-333). Leuven-Paris-Walpole, MA: Peeters

Hayes, J.W. (1985). Sigillate orientali. In Atlante delle forme ceramiche II. Ceramica fine romana nel bacino mediterraneo (tardo ellenismo e primo impero) (pp. 1-96). Rome: Istituto della Enciclopedia Italiana

Koczorowska, M., Osiak, W., and Zambrzycki, P. (2016). Selected conservation projects in Marina el-Alamein in the 2014 and 2015 seasons. PAM, 25, 185-192

Krencker, D., Krüger, E., Lehmann, H., and Wachtler, H. (1929). Die Trierer Kaiserthermen I. Ausgrabungsbericht und grundsätzliche Untersuchungen römischer Thermen [=Trierer Grabungen und Forschungen 1/1]. Augsburg: Filser

Eajtar, A. (2001). Two architectural terms: SKOYT $\Lambda \Omega \Sigma \mathrm{I} \Sigma$ and $\Sigma \mathrm{TIBA} \Sigma$ in an inscription from Marina el-Alamein, JJP, 31, 59-66

Majcherek, G. (2007). Aegean and Asia Minor amphorae from Marina el-Alamein. In S. Marchand and A. Marangou (eds), Amphores d'Égypte de la Basse Époque à l'époque arabe I [=CCE 8/1] (pp.9-31). Cairo: Institut français d'archéologie orientale

Majcherek, G. and Shennawi, A.A. (1992). Research on amphorae production on the northwestern coast of Egypt. CCE, 3, 123-136

Medeksza, S., Czerner, R. with G. Bąkowska, W. Grzegorek, R. Kucharczyk, J. Lis, and P. Zambrzycki (2011). Marina el-Alamein. Polish-Egyptian Restoration Mission: Conservation work in 2008. PAM, 20, 103-128

Medeksza, S., Czerner, R., Bąkowska-Czerner, G. with contributions by I. Fuks-Rembisz, W. Grzegorek, G. Majcherek, M. Mrozek-Wyscoka, and P. Zambrzycki (2012). Marina el-Alamein. Conservation work in the 2009 season. PAM, 21, 79-105

Nielsen, I. (1990). Thermae et balnea: The architecture and cultural history of Roman public baths I. Text. Aarhus: Aarhus University Press

Rieger, A.-K., and Möller, H. (2011). Kilns, commodities and consumers: Greco-Roman pottery production in Eastern Marmarica (Northwestern Egypt). AA, 2011(1), 141-170

Riley, J.A. (1979). Coarse pottery. In J.A. Lloyd (ed.), Excavations at Sidi Khrebish, Benghazi (Berenice) II [=Libya Antiqua Supplements 5] (pp. 91-467). Tripoli: Department of Antiquities, People's Socialist Libyan Arab Jamahirya

Tomber, R.S. (2006). The pottery. In V.A. Maxfield and D.P.S. Peacock (eds), Mons Claudianus: Survey and excavation, 1987-1993, III. Ceramic vessels and related objects [=FIFAO 54] (pp. 3-218). Cairo: Institut français d'archéologie orientale 